\title{
Mycobacterium marinum infections in man
}

Mycobacterium marinum, formerly known as 'Mycobacterium balnei', is a free-living organism which causes disease in fish and occasionally in man. When such infections occur in man they are usually associated with some aquatic activity, e.g. swimming, fishing, boating and keeping tropical fish. For this reason, the organism has been called a 'leisure-time pathogen' by Feldman, Long \& David (1974) and the disease a 'hobby hazard' by Heineman, Spitzer \& Pianphongsant (1972).

Mycobacterial infection of the skin, especially with $M$. tuberculosis, has been made complex by the plethora of synonyms bestowed upon the lesions by dermatologists, though Beyt et al. (1981) have attempted to reduce the problem to manageable proportions. With $M$. marinum infections, however, there is universal agreement that the source is exogenous and that infection occurs as a result of contamination of trivial skin lesions and is frequently connected in some way with a watery environment.

This paper reviews the history, microbiology, clinical features, treatment and epidemiology of the disease in man.

\section{HISTORY}

In 1886 Riehl \& Paltauf described a form of skin tuberculosis which they called tuberculosis cutis verrucosa (warty tuberculosis of skin). This usually occurred on the hands and arms of healthy individuals where it remained localized and ran a benign, self-limiting course. It rarely involved local lymph nodes and could easily be distinguished from the more serious and progressive forms of skin tuberculosis such as lupus vulgaris but nevertheless usually yielded Mycobacterium tuberculosis.

Lesions of this type were reported in users of swimming pools by Hellerström in 1939, and subsequently in 1944 and 1951. In the last of these three studies Hellerström reviewed his six cases, all of whom had suffered facial abrasions. 'Koch's bacilli' were seen in one case but cultures and guinea pig inoculations were all negative. Hellerström remarked that '... the condition may on safe grounds be diagnosed as tuberculous primary infection of the skin' and he thus referred to the disease as primary inoculation lupus vulgaris. One of Hellerström's six patients had received a minor injury in a swimming pool at the town of Örebro in Sweden. Similar lesions, developing subsequent to injuries received in swimming pools, were also reported in America (Cleveland, 1951; Tomach \& Franks, 1953; Rees \& Bennett, 1953) but again, no acid fast bacilli were cultured.

During the years 1949-50 an epidemic of self-limiting skin lesions occurred at the town of Örebro (Linell \& Norden, 1954). Eighty individuals were infected, of whom 75 were children; the lesions were mostly on the elbows. At first they were thought to be tuberculous but their origin remained a mystery until it was found 
that the five adult patients had one thing in common - they were all keen and regular swimmers.

In an attempt to establish the aetiology of these lesions biopsy material was sent to Professor Folke Linell at the University of Lund. Fortunately, he thought that M. ulcerans might have been responsible and he therefore incubated his cultures at 31 as well as at $37^{\circ} \mathrm{C}$. An acid fast bacillus was isolated at the lower temperature from 3 of 19 biopsies. An identical organism was recovered from the walls of the swimming pool used by the patients. Apart from not growing at $37^{\circ} \mathrm{C}$, these isolates differed from the classical tubercle bacillus in producing a yellow pigment on exposure to light and in the ease with which they emulsified in saline. As they appeared to be a new species the name ' $M$. balnei' (L. of the bath) was coined (Linell $\&$ Norden, 1954). Shortly after the epidemic at Örebro, a second outbreak occurred under similar circumstances, at the town of Vasteras and involved about 60 individuals (Zettergren et al. 1952). 'M. balnei' was isolated from 11 of 15 biopsies and also from the swimming pool.

There was, therefore, strong evidence that a new type of mycobacterial disease had been found, but to overcome any doubt Linell \& Norden (1954) inoculated themselves with the causative agent, elicited identical lesions and reisolated the organisms in culture. Koch's postulates were therefore fulfilled.

A similar outbreak associated with swimming and involving about 300 people occurred in Colorado, and was reported by Mollohan \& Romer (1961). Another occurred in Wales (Waddington, 1967). Similar incidents have also been reported more recently, by Dailloux, Morlot \& Sirbat (1980) in France and by Jünger \& Witzani (1981) in Germany.

Sporadic cases associated with swimming pools and with sea bathing have also been described (Evan Paz et al. 1976; Loria, 1976). Zeligman (1972) reported 18 cases resulting from minor injuries acquired while swimming, fishing or boating in Chesapeake Bay, U.S.A.

Swimming pools are not the only aquatic features associated with these granulomas. Philpott et al. (1963) referred to one case, not in their epidemic series, in which $M$. marinum had been transferred from a tropical fish tank to man, and Swift \& Cohen (1962) are usually credited with reporting the first case of fish tank granuloma. Others, from several countries, were made by Pegum (1967), U.K.; Barrow \& Hewitt (1971), U.K.; Hay, McCarthy \& Marks (1975), U.K.; Bourlond (1973), Belgium; Simonart (1973), Belgium; Brodhagen et al. (1980), Denmark; Engbaek, Thormann \& Bergmann (1980), Denmark; Nilsen \& Boe (1980), Sweden; Jünger \& Witzani (1981), Germany; Jänner, Reinel \& Kuhlwein (1983), Germany; Neidecken (1984), Germany; Monti et al. (1979), Italy; Horacek \& Ulicna (1973), Hungary ; Brown, Keim \& Bryan (1977), Canada ; Sauder \& Hanke (1978), Canada; Black, Rush-Munro \& Woods (1971), Australia; Faoagali et al. (1977), New Zealand; Maclellan \& Moon (1982), Australia/New Zealand; Saito et al. (1973), Japan; Wolinsky, Gomez \& Zimpfer (1972), U.S.A.

We have identified $M$. marinum from a patient's lesion and also from his fish or fish tank water on five occasions in the last few years, but unfortunately have not been able to follow up several other cases in the same way.

Infections arising from other aquatic activities have also been noted. Flowers (1970) described one that followed a bite by a captive dolphin. In the cases reported 
by Smith \& Jiji (1975) and Bailey et al. (1982) the patients' hands had been injured by fish fins, while one of Loria's patients had injured his hand while working on a boat engine (Loria, 1976).

A substantial proportion of cases, however, have either not been associated with water, or the histories obtained by the clinicians have not revealed any association with water. Jolly \& Seabury (1972) mention one infection after an 'abrasion on asphalt' in a school yard, two following injuries from rose thorns and one after a contusion related to an electrical installation. Another 'asphalt' case was reported by Arai, Nakajima \& Nagai (1984): a Japanese lady sustained a minor injury when she stumbled on an asphalt road outside a fish shop and her lesions became infected. The association with fish and with water in this case is rather tenuous.

The distribution of lesions in the cases where the source of infection is unknown or not revealed, however, closely follows that of the non-swimming-pool cases.

A disseminated infection following renal transplant was reported by Gombert et al. (1981). A second case was reported in a 16-month-old child whose father used the child's bath to clean out a fish tank (King, Fairly \& Rasmussen, 1983) but this may more closely resemble the case with multiple lesions described by Yamamoto et al. (1970).

\section{NOMENCLATURE AND TAXONOMY}

The name ' $M$. balnei' is no longer valid; in 1959 Bojalil found that the organism was identical with $M$. marinum, a species isolated in 1926 by Aronson from some marine fish, namely a sergeant-major (Abudefduf mauritii), three croakers (Micropogon undulatus) and two sea-bass (Centropristes striatus). By the law of chronological priority the earlier name is the correct one, and fortunately it also relates to the aquatic habit of the species. Another organism, named ' $M$. platypoecilus', recovered from lesions in the Mexican platyfish by Baker \& Hagen (1942) was also identified with M. marinum (Schaefer \& Davis, 1961). Not all pathogens of fish, however, belong to this species (see the reviews by Vogel, 1958; Parisot, 1958; Collins, Grange \& Yates, 1984).

In their descriptions of granulomatous lesions associated with the use of swimming pools, Zettergren (1952), Hellerström (1951) and Rees \& Bennett (1953) concluded that the disease was caused by $M$. marinum. Linell \& Norden (1954) did not accept this conclusion. On the basis of pathogenicity for mice they considered that ' $M$. balne $i$ ' was different from Aronson's organisms and this conclusion was supported by Aronson himself. Nevertheless, the former view proved to be correct, as clearly demonstrated by Bojalil in 1959 and the name ' $M$. balnei' was dropped.

Further difficulties with the name $M$. marinum occurred, however, because of the existence of an organism with a very similar name, ' $M$. marianum' (Suzanne \& Penso, 1953). Bojalil, Trujillo \& Cerbon (1962) placed this organism, along with a strain labelled 'M. marinum ATCC 8138 Battaglini' with $M$. scrofulaceum (Prissick \& Masson, 1956). In 1963 one of us (CHC) received three strains labelled $M$. marinum from the National Collection of Type Cultures. One of these was numbered 8138 . Tests showed that it was not $M$. marinum but a scotochromogen, 
probably M. scrofulaceum. The NCTC admitted a clerical error and according to the American Type Culture Collection catalogue there was no ATCC 8138. In the course of correspondence Bojalil (pers. comm.) found that he also had made a clerical error. Thus two errors, undoubtedly compounded by the existence of two very similar names, caused some confusion! ' $M$. marianum' has since been reduced to synonymy with $M$. scrofulaceum.

\section{BACTERIOLOGY}

M. marinum is a member of the slowly-growing group of mycobacteria, but its growth is more rapid than that of most members of this group. Indeed, in the identification system of Pattyn \& Portaels (see Jenkins, Pattyn \& Portaels, 1982) it is included with the rapid growers as, like others in that group, it shows putrescine diamine oxidase activity, although it resembles the slow growers in failing to produce abundant growth on peptone agar within 5 days. On immunodiffusion analysis, however, M. marinum is clearly placed among the slow growers on account of its possession of a group of antigens characteristic of the group (Stanford \& Grange, 1974). Superficially it resembles $M$. kansasii in producing a yellow pigment following exposure to light; the pigments formed by the two species are identical, but are different from those found in other chromogenic mycobacteria (Tarnok \& Tarnok, 1970). Furthermore, the two species are similar in their rate of growth (except on primary culture at $37^{\circ} \mathrm{C}$ ), and in their microscopic appearance.

Silcox \& David (1971) used numerical analysis to differentiate between $M$. marinum and $M$. kansasii, employing 53 tests on 63 strains of the former and 139 of the latter. The $M$. kansasii strains formed an homogenous cluster at $80-100 \%$ but the $M$. marinum strains clustered at $40-80 \%$ and further analysis of this group showed that it was heterogenous, made up of one large cluster containing three small subgroups, and two smaller clusters. Tsukamura (1976) included 12 strains of $M$. marinum and 11 of $M$. kansasii in a numerical classification of slowly growing mycobacteria and found that they were clearly differentiated from one another and from other species.

\section{Isolation}

The specimens submitted for laboratory examination must be exudates or biopsies. Cultures should be made for 'other organisms' including fungi, in the usual way and incubated at $37^{\circ} \mathrm{C}$. If necessary the material should be treated to eliminate other organisms, using one of the techniques employed in tuberculosis bacteriology, and then cultured in duplicate on Lowenstein-Jensen or other mycobacterial medium. One set of these cultures should be incubated at $30-33{ }^{\circ} \mathrm{C}$ and the other at $37^{\circ} \mathrm{C}$. Both sets should be examined after 7 days and then weekly for up to 6 weeks.

\section{Cultural and microscopic appearance}

On primary culture $M$. marinum will grow at $30-33^{\circ} \mathrm{C}$ in $7-10$ days but usually not at $37^{\circ} \mathrm{C}$. The occasional strains that grow at $37^{\circ} \mathrm{C}$ take longer to give visible growth. M. kansasii, which is occasionally isolated from skin lesions, grows at both 
Table 1. Principal diagnostic differences between M. marinum and M. kansasii

\begin{tabular}{lccc}
\multicolumn{1}{c}{ Property } & $M$. marinum & M. kansasii & Ref.* $^{*}$ \\
Growth at $37^{\circ} \mathrm{C}$ & - & + & 1 \\
Nitrate reductase & - & + & 2 \\
Pyrazinamidase & + & - & 2 \\
Growth on hydroxylamine, & + & - & 2 \\
$250 \mathrm{mg} / \mathrm{l}$ & & & 2 \\
Growth on isoxyl, & + & - & 3 \\
$50 \mathrm{mg} / \mathrm{l}$ & + & - & 4 \\
Allantoinase & + &
\end{tabular}

temperatures in 10-14 days. After $7-10$ days at $30-33{ }^{\circ} \mathrm{C}$ colonies of $M$. marinum are about $2 \mathrm{~mm}$ in diameter, shiny and smooth. Wrinkled and rough colonies are occasionally seen. Cultures showing colonies should be placed about $50 \mathrm{~cm}$ from a $40 \mathrm{~W}$ tungsten filament lamp for about $1 \mathrm{~h}$ or left in daylight on the bench for 1 or $2 \mathrm{~h}$. They should then be re-incubated overnight. M. marinum and M. kansasii are photochromogens and after illumination and re-incubation their colonies will be bright yellow.

$M$. marinum will grow on blood agar and on glycerol agar in 7-10 days, but not on MacConkey agar.

In microscopic preparations stained by the Ziehl-Neelsen method the cells of $M$. marinum, like those of $M$. kansasii, are elongated and barred or beaded, although shorter and more solidly staining forms may be seen.

\section{Identification}

The most important tests are those that differentiate $M$. marinum from $\boldsymbol{M}$. kansasii. Growth at $30-33{ }^{\circ} \mathrm{C}$ and not at $37^{\circ} \mathrm{C}$ on the primary culture is a good guide, but not wholly reliable. Some strains, depending on the constituents of the culture medium, will grow at the higher temperature (Schaefer \& Davis, 1961). Temperature tests are not reliable on subcultures as most strains adapt rapidly to laboratory conditions and subcultures will usually grow at $37^{\circ}$ and at $25^{\circ}$ and may even grow at $20^{\circ} \mathrm{C}$.

Silcox \& David (1971) suggest that the nitratase test, ability to grow in media containing $10 \mu \mathrm{g} / \mathrm{ml}$ of thiacetazone, possession of an arylsulphatase, sensitivity to kanamycin and ability to grow in less than seven days differentiated $M$. marinum from $M$. kansasii.

Other properties of $M$. marinum include: allantoinase (Tsukamura, 1967);

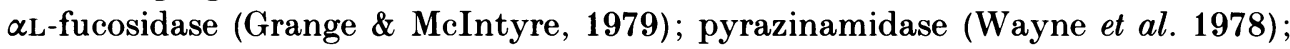
picric acid reduction (Kazda \& $\mathrm{Hampl}, 1965$ ); resistance to amithiozone, $10 \mu \mathrm{g} / \mathrm{ml}$; hydroxylamine, $250 \mu \mathrm{g} / \mathrm{ml}$; rifampicin, $25 \mu \mathrm{g} / \mathrm{ml}$ (Tsukamura et al. 1973); and resistance to isoxyl, $50 \mu \mathrm{g} / \mathrm{ml}$ (Wayne et al. 1978). The techniques used in these tests are discussed by Tsukamura et al. (1973).

The properties of $M$. marinum, compared with those of $M$. kansasii are shown in Table 1. 
Table 2. Minimal inhibitory concentration (MIC) of antibiotic to M. marinum

\begin{tabular}{|c|c|c|c|c|c|c|}
\hline \multirow[b]{2}{*}{ Antibiotic } & \multicolumn{2}{|c|}{$\begin{array}{l}\text { Number of } \\
\text { strains tested }\end{array}$} & \multicolumn{2}{|c|}{$\begin{array}{l}\text { MIC range } \\
(\mu \mathrm{g} / \mathrm{ml})\end{array}$} & \multicolumn{2}{|c|}{$\begin{array}{c}\text { MIC } 50 \% \\
(\mu \mathrm{g} / \mathrm{ml})\end{array}$} \\
\hline & A & B & A & B & A & B \\
\hline Tetracycline & 16 & 19 & $3 \cdot 1-50$ & $1-16$ & 5 & 4 \\
\hline Doxycycline & 16 & 19 & $1 \cdot 2-20$ & $1-8$ & 5 & 4 \\
\hline Minocycline & 16 & 19 & $2 \cdot 5-20$ & $1-4$ & 5 & 2 \\
\hline Gentamicin & 7 & 16 & 5-20 & $16-32$ & $>10$ & 32 \\
\hline Kanamycin & 16 & 16 & $0 \cdot 3-10$ & $2-4$ & $1 \cdot 2$ & 2 \\
\hline Amikacin & 16 & 16 & $1 \cdot 2-5$ & $1-4$ & $1 \cdot 2$ & 2 \\
\hline Tobramycin & ND & 16 & ND & $16-64$ & ND & 32 \\
\hline Streptomycin & ND & 16 & ND & 8-32 & ND & 16 \\
\hline Erythromycin & 16 & ND & $1 \cdot 2-40$ & ND & $6 \cdot 2$ & ND \\
\hline Trimethoprim & 16 & ND & $1 \cdot 2-20$ & ND & 5 & ND \\
\hline
\end{tabular}

A, Sanders \& Wolinsky, 1980; B, Wallace \& Wiss, 1981; ND, not done.

The tests that are easiest to perform in a clinical laboratory employ media and techniques that are normally available in tuberculosis laboratories. For clinical purposes a photochromogen that grows on Lowenstein-Jensen medium containing $10 \mu \mathrm{g} / \mathrm{ml}$ of thiacetazone (Vestal \& Kubica, 1967); gives a negative nitratase test (Kazda \& Hampl, 1965; Käppler, 1968) and fails to hydrolyse Tween 80 in 7 days (Wayne, Doubek \& Russell, 1964; Käppler, 1968) is almost certainly M. marinum.

\section{ANTIBIOTIC RESISTANCE}

Early studies showed that $M$. marinum was resistant to isoniazid, PAS and thiosemicarbazone and partially resistant to streptomycin at $4 \mu \mathrm{g} / \mathrm{ml}$ (Linell \& Norden, 1954; Schaefer \& Davis, 1961). Barrow \& Hewitt (1971) reported a strain that was resistant to streptomycin $(10 \mu \mathrm{g} / \mathrm{ml})$, and rifampicin $(20 \mathrm{~g} / \mathrm{ml})$ as well as to PAS, isoniazid, thiacetazone and capreomycin, but sensitive to trimethoprim with sulphamethoxazole. Later, Cunningham, White \& Samman (1978) reported a trimethoprim resistant strain in the U.K. and all of the nine isolates from a single source in Israel by Evan Paz et al. (1976) were also resistant to cotrimoxazole. The other antibiotics used in recent years are the tetracyclines. Torres, Sands \& Sanders (1978) studied 32 clinical isolates from the U.S.A. and concluded that most of them were sensitive to doxycycline and minocycline.

A range of MIC values from two publications is shown in Table 2.

\section{Diagnosis}

\section{CLINICAL FEATURES}

Lesions caused by $M$. marinum closely resemble those of sporotrichosis - an infection caused by the soil fungus Sporothrix schenkii (Dickey, 1968). They usually occur on the elbows, knees and feet in swimming pool related cases and on the hands and fingers of fish fanciers. They have also been reported on the bridge of the nose and the chin. A history of a recent injury sustained in a swimming pool or other watery environment, or while handling fish or working with an aquarium is helpful.

On presentation at 3-5 weeks duration the lesions are typically $1-2.5 \mathrm{~cm}$ in 
diameter. They are variously described as non-tender inflammatory nodules, as ulcerated granulomata or as resembling the warty lesions of cutaneous tuberculosis (although this may be more typical of older lesions). In a proportion of cases there may be sporotrichoid spread: further nodular lesions appearing on the hands and arms following the line of the lymphatic ducts as in sporotrichosis. Axillary pain and lymphadenopathy are usually absent nowever (Brown, Keim \& Bryan, 1977; Cortez \& Pankey, 1973). Some authors have reported tenosynovitis following a penetrating injury to the hand, e.g. by fish spines, and also bursitis of the knee in similar circumstances (Winter \& Runyon, 1965; Hay, McCarthy \& Marks, 1975; Wayne et al. 1981).

In an immunocompromised patient, $M$. marinum caused the formation of a deeply undermined ulcer, similar to those seen in M. ulcerans infection (Meyers, 1981).

\section{Skin tests}

Although infection by $M$. marinum induces dermal reactivity to skin-testing reagents prepared from the organism in some patients the size of the reaction is similar to that induced by standard PPD or to analogous reagents prepared from other slowly-growing mycobacteria (Judson \& Feldman, 1974; Jolly \& Seabury, 1972 ; Schaefer, Blatman \& Bravo, 1962). Accordingly, skin testing is of little value in this infection.

\section{Histology}

Histological examination reveals cutaneous lesions with slight to moderate epidermal hyperplasia. Parakeratotic scales are seen in lesions of less than 6 months duration, while other lesions tend to show hyperkeratotic scales. The dermis contains granulomas composed of lymphocytes and epithelioid cells and there is often a more diffuse cell infiltrate. Langhans' giant cells occasionally occur but caseation is unusual. There may be evidence of secondary infection and ulceration. Older healing lesions reveal non-specific focal aggregates of lymphocytes. Lesions are described as comparable with mycobacterial disease in the presence of a well developed cell-mediated immunity (Marsch, Nurnberger \& Stuttgen, 1978). It is agreed by most workers who have studied the histopathology that acid fast bacilli appear to be absent or at the most scanty but Schaefer \& Davis (1961), who examined 15 specimens obtained during a large outbreak associated with a swimming pool, reported that acid fast bacilli were present in 9 of the tissue sections; positive cultures were obtained from 12.

\section{TREATMENT}

Few clinicians have seen enough cases to make definitive statements about the best form of therapy and the self-limiting nature of the infection renders the evaluation of the therapeutic regimens difficult. Lesions will generally resolve with no treatment other than excision and drainage, although this may result in a long period of infection (see, e.g. Morgan \& Blowers, 1964; Brown, Keim \& Bryan, 1977). Heat treatment has been advocated (see, e.g. Aaronson \& Park, 1974) but there 
Table 3. Site of M. marinum lesions as percentage of sites involved

Swimming pool epidemics

Hand

Arm except elbow

Elbow

Knee

Leg except knee

Other sites

Total patient (number

sporotrichoid)

Site not recorded

(Feldman, Long \&

David, 1974)

Grand Total patients

Hand

Arm except elbow

Elbow

Knee

Leg except knee

Other sites

Total patient (number

sporotrichoid)

Site not recorded

(Feldman, Long \&

David, 1974)

Grand Total patients

\begin{tabular}{|c|c|c|c|}
\hline \multicolumn{4}{|c|}{ Swimming pool epidemics } \\
\hline $\begin{array}{c}\text { Sweden: } \\
\text { Zettergren } \\
\text { et al. (1952) }\end{array}$ & $\begin{array}{c}\text { Sweden: } \\
\text { Linell \& } \\
\text { Norden } \\
(\mathbf{1 9 5 4 )}\end{array}$ & $\begin{array}{l}\text { USA: } \\
\text { Philpott } \\
\text { et al. } \\
(\mathbf{1 9 6 3 )}\end{array}$ & $\begin{array}{c}\text { Wales: } \\
\text { Waddington } \\
(1967)\end{array}$ \\
\hline 0 & 0 & $0 \cdot 7$ & 0 \\
\hline 0 & 0 & 0 & 0 \\
\hline 100 & $98 \cdot 6$ & 89 & 82 \\
\hline 0 & $1 \cdot 4$ & $7 \cdot 4$ & $14 \cdot 5$ \\
\hline 0 & 0 & $2 \cdot 9$ & 3.5 \\
\hline 0 & 0 & 0 & 0 \\
\hline 60 & 74 & 269 & 81 \\
\hline- & - & - & - \\
\hline 60 & 74 & 269 & 81 \\
\hline \multicolumn{4}{|c|}{ Collected cases from literature* } \\
\hline $\begin{array}{l}\text { Aquarium } \\
\text { associated }\end{array}$ & $\begin{array}{c}\text { Marine } \\
\text { or fresh- } \\
\text { water origin }\end{array}$ & $\begin{array}{l}\text { Other } \\
\text { origin }\end{array}$ & $\begin{array}{l}\text { Source } \\
\text { not known } \\
\text { or not } \\
\text { recorded }\end{array}$ \\
\hline 97 & 47 & 88 & 59 \\
\hline 3 & 12 & 0 & 10 \\
\hline 0 & 0 & 0 & 0 \\
\hline 0 & 23 & 12 & 17 \\
\hline 0 & 11 & 0 & 10 \\
\hline 0 & 7 & 0 & 4 \\
\hline $59(34)$ & $58(10)$ & $8(1)$ & $29(6)$ \\
\hline 24 & 21 & 7 & 27 \\
\hline 83 & 79 & 15 & 56 \\
\hline
\end{tabular}

is no firm evidence that this is better than drainage alone. Antibiotic therapies fall into three classes: rifampicin plus another drug, frequently ethambutol; trimethoprim plus sulphonamides; and tetracyclines, especially minocycline. Although the evidence for these three is about evenly balanced, there is a preference for minocycline in the more recent descriptions. Examples of these therapies are given by Wolinsky, Gomez \& Zimpfer (1972); Loria (1976); and Kirk \& Kaminsky (1976).

Jolly \& Seabury (1972) described 31 cases seen in America by local clinicians who carried out their own therapies; they reported that in 13 excision was performed, including one amputation. Heat lamps were used in two cases, and 
chemotherapy (unspecified) in seven. Arai, Nakajima \& Nagai (1984) described 75 cases seen in Japan and also found a variety of therapies; they reported that minocycline was twice as effective as rifampicin in speed of healing (1.5 against 3.5 months). Local steroids should be avoided as these exacerbate the lesions and enhance sporotrichoid spread (Aaronson \& Park, 1974).

\section{EPIDEMIOLOGY}

As indicated above, most infections with $M$. marinum are associated with water; the two aquatic sources most often involved are swimming pools and aquaria - hence swimming pool granuloma and fish tank granuloma, the 'hobby hazards' referred to in the introduction.

\section{Swimming pool granuloma}

Most of the early proven cases of $M$. marinum infections occurred in epidemics associated with swimming pools, and the lesions usually occurred on the elbows, with the knees as the second most common site (Table 3). In the first report, the outbreak in Sweden, Linell \& Norden (1954) reported on 80 patients, most of whom had lesions on the elbow, although 'a few' had lesions on the knee. Most of the minor injuries that became infected probably occurred whilst children were climbing out of the pool, as many children scorn the use of the steps and lever themselves out using their elbows and knees.

\section{Fish tank granuloma ('Fish fanciers finger')}

Aquarium-associated cases usually occur singly and involve fingers and hands that have already sustained minor injuries as a result of other activities (e.g. gardening), although sometimes the injury arose from the fish tank itself. In some incidents the organisms were also recovered from the fish or the aquaria. The distribution shown in Table 3 is derived from many publications citing one or two, rarely more, cases. Not all of these publications are cited in the References. In one case (Månsson et al. 1970) the bacilli were transferred by water-fleas, used as fish food, from a pond.

\section{Other sources}

Like aquarium-associated infections, cases connected with fishing, boating and aquatic sports usually occur singly and the lesions are almost always on the hands, as are most infections that do not appear to be connected with water.

\section{Epidemiological investigations}

The usual case histories tend to be inadequate and the investigator needs to seek information about leisure activities. The history of a minor injury, e.g. from thorns or spines during gardening activities, may obscure the fact that the patient had been swimming or that he kept tropical fish. Laboratory investigations should include culture of water from swimming pools even where chlorination appears sufficient (Beurey et al. 1981), material from behind loose tiles (Thomas, 1967) and 
the inner surfaces of pipes. Likewise, in possible cases of fish tank granulomas, the water and the sand from the bottoms of fish tanks should be cultured, as well as the scales of live fish and the scales and skin of those that are dead or moribund.

It is worth noting here that infections by $M$. marinum are recognized as compensatable occupational diseases in Japan (Arai, Nakajima \& Nagai 1984).

\section{CUTANEOUS INFECTIONS CAUSED BY OTHER MYCOBACTERIA}

It is necessary to guard against the assumption that all cutaneous mycobacterial infections, even all sporotrichoid infections, are associated with $M$. marinum. A few cases have been recorded in which cellulitis or sporotrichoid cutaneous infection was caused by M. kansasii (Maberry, Mullins \& Stone, 1965; Owens \& McBride, 1969; Fraser et al. 1975; Hirsch \& Saffold, 1976; Dore, Collins \& Mankiewicz, 1979; Rosen, 1983). Similarly, infections, including sporotrichoid forms, have been ascribed to M. chelonei (Bernstadt, 1974; Greer, Grose \& Martensen, 1979; Fenske \& Millns, 1981), to M. szulgai (Sybert, Tsou \& Garagusi, 1977), to unidentified slow-growing scotochromogens (Knox et al. 1961; Cott, Carter \& Sall, 1967), and to M. gordonae (Shelley \& Folkens, 1984).

In recent years a new mycobacterial pathogen $M$. haemophilum has emerged as a cause of skin lesions in man. This species, described by Sompolinsky et al. (1978, 1979 ) is so named because it requires iron supplements, usually ferric ammonium citrate or haemin, for growth. Its colonies are off-white or pale yellow and, like M. marinum, it is psychrophilic. It is easily differentiated from the latter, however, by its absence of catalase and urease activity, its failure to grow on iron-free media and to develop pigment on exposure to light. It is metabolically rather inert. To date, all infections have occurred in immunosuppressed individuals, notably renal transplant recipients (Sompolinsky et al. 1978; Mezo et al. 1979; Dawson \& Jennis, 1980; Davis et al. 1982; Branger et al. 1983; Moulsdale et al. 1983). In one report the infection was initially thought to be due to $M$. marinum as the patient's daughter had kept goldfish that had died during the preceding year (Moulsdale et al. 1983). In view of the occurrence of such infections it appears advisable to inoculate skin biopsies, particularly if they are from immunosuppressed patients, on to media supplemented with ferric ammonium citrate as well as on standard media.

Finally, there have been a number of ulcerating skin lesions containing acid-fast bacilli reported in non-immunosuppressed patients living in the region of the border between Canada and the U.S.A. (Feldman \& Hershfield, 1974). The bacilli could not be cultured, raising the possibility that these cases represent yet another mycobacterial species and disease.

C. H. Collins and J. M. Grange

Department of Microbiology, Cardiothoracic Institute,

University of London, Fulham Road, London SW3 6 HP

W. C. Noble

Department of Microbiology, Institute of Dermatology, University of London,

St. John's Hospital for Diseases of the Skin, Homerton Grove London E9 6 BX

M. D. YATES

Regional Centre for Tuberculosis Bacteriology, Public Health Laboratory,

Dulwich Hospital, East Dulwich Grove, London SE22 8QF. 


\section{REFERENCES}

Aaronson, C. M. \& Park, C. H. (1974). Sporotrichoid infection due to Mycobacterium marinum. Lesion exacerbated by corticosteroid infiltration. Southern Medical Journal 67, 117-118.

Arai, H., Nakajima, H. \& Nagai, R. (1984). Mycobacterium marinum infection of the skin in Japan. Journal of Dermatology 11, 37-42.

ARonson, J. D. (1926). Spontaneous tuberculosis in salt water fish. Journal of Infectious Disease 39, 315-320.

Bailey, J. P., Stevens, J., Bell, W. M., Mealing, H. G., Loebl, D. H. \& Cook, E. H. (1982). Mycobacterium marinum infection: a fishy story. Journal of the American Medical Association 247, 1314.

BAKER, J. A. \& HAGEN, W. A. (1942). Tuberculosis of the Mexican flatfish (Platypoecilus maculatus). Journal of Infectious Disease 70, 248-252.

BARROw, G. I. \& HewITT, M. (1971). Skin infection with Mycobacterium marinum from a tropical fish tank. British Medical Journal i, 505-506.

BERNSTADT, S. (1974). Mycobacterium borstelense isolated from aquarium fishes with tuberculous lesions. Scandinavian Journal of Infectious Diseases 6, 241-246.

Beurey, J., Weber, M., Vignaud, J-M. \& Dailloux, M. (1981). Mycobactérioses cutánées: enquête épidémiologique. Annales de Dermatologie et Vénéreologie (Paris) 108, 439-442.

Beyt, B. E., Ortbals, D. W., Santacruz, D. J., Kobayashi, G. S., Eisen, A. Z. \& Medoff, G. (1981). Cutaneous mycobacterioses: analysis of 34 cases with a new classification of the diseases. Medicine 60, 95-109.

Black, H., Rush-Munro, F. M. \& Woods, G. (1971). Mycobacterium marinum infection acquired from tropical fish tanks. Australian Journal of Dermatology 12, 155-164.

Bojalil, L. F. (1959). Estudio comparativo entre Mycobacterium marinum y Mycobacterium balnei. Revista Latinoamericano de Microbiologia 2, 167-174.

Bojalil, L. F., Cerbon, J. \& Trujillo, J. (1962). Adansonian classification of mycobacteria. Journal of General Microbiology 28, 333-346.

Bourlond, A. (1973). Granulome des piscines ou malade des aquariums? Archives Belges de Dermatologie 29, 337-338.

Brodhagen, H., Engbaek, H. C., Veien, N. K. \& Vergmann, B. (1980). Cutaneous infection with Mycobacterium marinum. Ugeskrift for Laeger 142, 1880-1882.

Branger, B., Oules, R., Gouby, A., Malbos, S., Coske, E., Asencio, J., Fourcade, J., Miou, C. \& Ramuz, M. (1983). Mycobacteriose cutanée à Mycobacterium haemophilum chez un transplante rénal. Presse Medicale 12, 2699.

Brown, J., KeIM, M. \& Bryan, L. E. (1977). Infection of the skin by Mycobacterium marinum. Canadian Medical Association Journal 117, 912-914.

Cleveland, D. E. H. (1951). Possible tuberculous skin infection from a swimming pool. Acta Dermatovenereologica (Stockholm) 31, 147-152.

Collins, C. H., Grange, J. M. \& Yates, M. D. (1984). Mycobacteria in water. Journal of Applied Bacteriology 57, 193-211.

Cortez, L. M. \& PANkey, G. A. (1973). Mycobacterium marinum infections of the hand. Journal of Bone and Joint Surgery (American volume) $55 \mathrm{~A}, 363-370$.

COTT, R. E., CARTER, D. M. \& SALL, T. (1967). Cutaneous disease caused by atypical mycobacteria. Archives of Dermatology 95, 259-268.

Cunningham, M. J., White, P. M. \& Samman, P. D. (1978). Co-trimoxazole resistant Mycobacterium marinum. British Journal of Dermatology 99, 597.

Dailloux, M., Morlot, M. \& Sirbat, C. (1980). Study of factors affecting the presence of atypical mycobacteria in water of a swimming pool. Revue Epidémiologique de Santé Publique 28, 299-306.

Davis, B. E., Brumbach, J., Sanders, W. J. \& Wolinsky, E. (1982). Skin lesions caused by Mycobacterium haemophilum. Annals of Internal Medicine 97, 723-724.

Dawson, D. J. \& Jennis, F. (1980). Mycobacteria with a growth requirement for ferric ammonium citrate, identified as Mycobacterium haemophilum. Journal of Clinical Microbiology 11, 190-192.

DiCKey, R. F. (1968). Sporotrichoid mycobacteriosis caused by Mycobacterium marinum (balnei). Archives of Dermatology 98, 385-391. 
Dore, N., Collins, J-P. \& Mankiewicz, E. (1979). A sporotrichoid Mycobacterium kansasii infection of the skin treated with minocycline hydrochloride. British Journal of Dermatology 101, 75-79.

Engbaek, H. C., Thormann, J. \& Bergmann, B. (1980). Aquarium-borne Mycobacterium marinum granuloma. Scandinavian Journal of Infectious Disease 12, 74-78.

Evan Paz, Z., Hass, H., Sacks, I. \& Rosenmann, E. (1976). Mycobacterium marinum skin infections mimicking leishmaniasis. British Journal of Dermatology 94, 435-442.

Faoagali, J. L., Muir, A. D., Sears, P. J. \& Paltridge, G. P. (1977). Tropical fish tank granuloma. New Zealand Medical Journal 85, 332-335.

Feldman, R. A. \& Hershfield, E. (1974). Mycobacterial skin infections by an unidentified species. A report of 29 patients. Annals of Internal Medicine 80, 445-452.

Feldman, R. A., Long, M. W. \& David, H. L. (1974). Mycobacterium marinum: a leisure time pathogen. Journal of Infectious Disease 129, 618-621.

Fenske, N. A. \& Millns, J. L. (1981). Resistant cutaneous infection caused by Mycobacterium chelonei. Archives of Dermatology 117, 151-153.

Flowers, D. J. (1970). Human infection due to Mycobacterium marinum after a dolphin bite. Journal of Clinical Pathology 23, 475-477.

Fraser, D. W., Buxton, A. E., NaJi, A., Barker, C. F., Rudnick, M. \& Weinstein, A.J. (1975). Disseminated Mycobacterium kansasii infection presenting as a cellulitis in a recipient of a renal homograft. American Review of Respiratory Disease 112, 125-129.

Gombert, M. E., Goldstein, E. J. C., Corrado, M. L., Stein, A. J. \& Butt, K. H. M. (1981). Disseminated Mycobacterium marinum infection after renal transplantation. Annals of Internal Medicine 94, 486-487.

Goodfellow, M. \& WAyne, L. G. (1982). Taxonomy and Nomenclature. In The Biology of the Mycobacteria, vol. 1 (ed. C. Ratledge and J. L. Stanford), pp. 471-521. London and New York: Academic Press.

Grange, J. M. \& McIntyre, G. (1979). Fluorogenic glycosidase substrates: their use in the identification of some slow growing mycobacteria. Journal of Applied Bacteriology 47, 285-288.

Greer, K. E., Gross, G. P. \& Martensen, S. H. (1979). Sporotrichoid cutaneous infection due to Mycobacterium chelonei. Archives of Dermatology 115, 738-739.

Hay, R. L., McCarthy, O. R. \& Marks, J. (1975). Fish tank granuloma. British Medical Journal i, 268.

Heineman, H. S., Spitzer, S. \& Pianphongsant, T. (1972). Fish tank granuloma. A hobby hazard. Archives of Internal Medicine 130, 121-123.

Hellerström, S. (1939). Contribution à la connaissance de l'infection tuberculeuse de la peau et de la muqueuse. Acta Dermatovenereologica (Stockholm) 20, 276-301.

Hellerström, S. (1951). Collected cases of inoculation lupus vulgaris. Acta Dermatovenereologica (Stockholm) 31, 194-211.

Hellerström, S. \& Hallberg, V. (1944). Existe-t-il un lupus d-inoculation primaire? Acta Dermatovenereologica (Stockholm) 24, 298.

Hirsch, F. S. \& SAFFold, O. E. (1976). Mycobacterium kansasii infection with dermatologic manifestations. Archives of Dermatology 112, 706-708.

Hó̉ÁCEK, J. \& ULIČnÁ, L. (1973). Mycobacterium balnei aus kohlengrubenwassern als ursache der Tuberculosis verrucosa cutis. Hautarzt 24, 126-128.

Jänner, M., Reinel, D. \& Kuhlwein, A. (1983). Infektion mit Mycobacterium marinum aus einem Aquarium. Hautarzt 34, 635-637.

Jenkins, P. A., Pattyn, S. R. \& Portaels, F. (1982). Diagnostic bacteriology. In The Biology of the Mycobacteria, vol. 1 (ed. C. Ratledge and J. L. Stanford), pp. 441-470. London and New York: Academic Press.

Jolly, H. W. \& Seabury, J. H. (1972). Infections with Mycobacterium marinum. Archives of Dermatology 106, 32-36.

Judson, F. N. \& Feldian, R. A. (1974). Mycobacterial skin tests in humans 12 years after infection with Mycobacterium marinum. American Review of Respiratory Disease 109, 544-547.

JÜNGER, H. \& WITZANI, R. (1981). 'Swimming-pool granuloma'-infection of skin with Mycobacterium marinum. Zeitschrift für Hautkrankheiten 56, 16-18.

KäPPLER, W. (1968). Zur Taxonomie der Gattung Mycobacterium. 1. Klassifizierung langsam wachsende Mykobakterien. Zeitschrift für Tuberkulose 129, 321-328. 
Kazda, J. \& Hampl, J. (1965). Über der Nachweis einiger Reduktasen zur Differenzierung der Mykobakterien. Zentralblatt für Bakteriologie, Parasitenkunde, Infektionskrankheiten und Hygiene (Abt. 1, Orig.) 197, 362-367.

King, A. J., Fairley, J. A. \& Rasmussen, J. E. (1983). Disseminated cutaneous Mycobacterium marinum infection. Archives of Dermatology 119, 268-270.

Kirk, J. \& Kaminsky, G. W. (1976). Mycobacterium marinum infection. Australian Journal of Dermatology 17, 111-116.

Knox, J. M., Gever, S. G., Freeman, R. G. \& Whitcomb, F. (1961). Atypical acid-fast organism infection of the skin. Archives of Dermatology 84, 386-391.

Linell, F. \& Norden, A. (1954). Mycobacterium balnei: a new acid-fast bacillus occurring in swimming pools and capable of producing skin lesions in humans. Acta Tuberculosea Scandinavica Supplement 33, 1-84.

LORIA, P. R. (1976). Minocycline hydrochloride treatment for acid-fast infection. Archives of Dermatology 112, 517-519.

MaberRy, J. D., Mullins, J. R. \& Stone, O. J. (1965). Cutaneous infection due to Mycobacterium kansasii. Journal of the American Medical Association 194, 1135-1137.

MacLellan, D. G. \& Moon, M. (1982). Fish tank granuloma: a diagnostic dilemma. Australian and New Zealand Journal of Surgery 52, 189-192.

MÅnsson, T., Brehmer-Andersson, E., Wittbeck, B. \& Grubb, R. (1970). Aquarium-borne infection with Mycobacterium marinum. Acta Dermatovenereologica (Stockholm) 50, 119-124.

Marsch, W. Ch., Nurnberger, F. \& Stuttaen, G. (1978). The ultrastructure of Mycobacterium marinum granuloma in man. Archives of Dermatological Research 262, 205-207.

Meyers, W. M. (1981). Mycobacterial infections of the skin. In Medical Microbiology and Infectious Diseases (ed. I. A. Braude), pp. 1596-1610. Philadelphia: W. B. Saunders.

Mezo, A., Jennis, F., McCarthy, S. W. \& Dawson, D. J. (1979). Unusual mycobacteria in five cases of opportunistic infections. Pathology 11, 377-384.

Mollohan, C. S. \& Romer, M. S. (1961). Public health significance of swimming pool granuloma. American Journal of Public Health 51, 883-891.

Monti, M., Berti, E., Santambrogio, A. \& Alessi, E. (1979). Micobatteriosi cutanea dei acquari. Una patologia trasmessa all'uomo del pesce. Bolletino dell'Istituto Sieroterapica Milanese 58, 429-434.

Morgan, J. K. \& Blowers, R. (1964). Swimming pool granuloma in Britain. Lancet i, 1034-1036.

Moulsdale, M. T., Harper, J. M., Thatcher, G. \& Dunn, B. L. (1983). Infection with Mycobacterium haemophilum, a metabolically fastidious acid fast bacillus. Tubercle 64, 29-36.

Niedecken, H. W. (1984). Das Schwimmbadgranulom-eine atypische Mykobakteriose. Hautarzt 35, 373-376.

Nilsen, A. \& Boe, O. (1980). Fish tank granuloma. Acta Dermatovenereologica (Stockholm) 60, 451-452.

Owens, D. W. \& McBride, M. E. (1969). Sporotrichoid cutaneous infection with Mycobacterium kansasii. Archives of Dermatology 100, 54-58.

Parisot, T. J. (1958). Tuberculosis in fish: A review of the literature with a description of the disease in salmonid fish. Bacteriological Reviews 22, 240-245.

Pegum, J. S. (1967). Clinical features of some atypical mycobacterial infections. Transactions of the St John's Hospital Dermatological Society 53, 119-121.

Philpott, J. A., Woodburne, A. R., Philpott, O. S., Schaefer, W. B. \& Mollohan, C. S. (1963). Swimming pool granuloma: a study of 290 cases. Archives of Dermatology 88, 158-162.

Prissick, F. H. \& Masson, A. M. (1956). Cervical lymphadenitis in children caused by chromogenic mycobacteria. Canadian Medical Association Journal 75, 798-803.

Rees, R. B. \& Bennett, J. H. (1953). Granuloma following swimming pool abrasion. Journal of the American Medical Association 152, 1606-1610.

Riehl, G. \& Paltauf, R. (1886). Tuberculosis Verrucosa Cutis. Einer bisher noch nicht beschriebene Form von Hauttuberculose. Vierteljahrschrift für Dermatologie (Wien) 13, 19-49.

Rosen, T. (1983). Cutaneous Mycobacterium kansasii infection presenting as cellulitis. Cutis 31, $87-89$.

Saito, H., Yamamoto, S., Yamura, T., Maeda, M., Seo, K. \& Fujiwara, Y. (1973). Sporotrichoid Mycobacterium marinum infection in a child. Hiroshima Journal of Medical Science 22, 181-187. 
Sanders, W. J. \& Wolinsky, E. (1980). In vitro susceptibility of Mycobacterium marinum to eight antimicrobial agents. Antimicrobial Agents and Chemotherapy 18, 529-531.

SAUder, D. N. \& HANKe, C. W. (1978). Mycobacterium marinum infections of the skin. Canadian Medical Association Journal 118, 900-901.

Schaefer, W. B., Blatman, S. \& Bravo, L. (1962). Tuberculin sensitivity in children infected with Mycobacterium balnei. Paediatrics 29, 404-408.

Schaeffer, W. B. \& Davis, C. L. (1961). A bacteriologic and histopathologic study of skin granuloma due to Mycobacterium balnei. American Review of Respiratory Disease 84, 837-844.

Shelley, W. B. \& Folkens, A. T. (1984). Mycobacterium gordonae infection of the hand. Archives of Dermatology 120, 1064-1065.

Silcox, V. A. \& David, H. L. (1971). Differential identification of Mycobacterium kansasii and Mycobacterium marinum. Applied Microbiology 21, 327-334.

Simonart, J. M. (1973). La maladie des aquariums. Archives Belges de Dermatologie 28, 151-154.

Smith, A. G. \& JiJI, R. M. (1975). Cutaneous infection due to a rough variant of Mycobacterium marinum. American Journal of Clinical Pathology 64, 263-270.

Sompolinsky, D., Lagziel, A., Naveh, D. \& Yankilevitz, T. (1978). Mycobacterium haemophilum sp.nov., a new pathogen of humans. International Journal of Systematic Bacteriology 28 , $57-75$.

Sompolinsky, D., Lagziel, A. \& Rosenberg, I. (1979). Further studies on a new pathogenic mycobacterium (M. haemophilum sp.nov.). Canadian Journal of Microbiology 25, 217-226.

Stanford, J. L. \& Grange, J. M. (1974). The meaning and structure of species as applied to mycobacteria. Tubercle 55, 143-152.

Suzanne, M. \& Penso, G. (1953). Sulla identita specifica de considetto 'Ceppa Chauvire' Mycobacterium marianum n.sp. Riassunti della Communicazioni del VI Congresso Internazionale Microbiologia (Rome) 2, 655-656.

Swift, S. \& Cohen, H. (1962). Granulomas of the skin due to Mycobacterium balnei after abrasions from a fish tank. New England Journal of Medicine 267, 1244-1245.

Sybert, A., Tsou, E. \& Garagusi, V. F. (1977). Cutaneous infections due to Mycobacterium szulgai. American Review of Respiratory Disease 115, 695-698.

TARNOK, I. \& TARNOK, Zs. (1970). Carotenes and xanthophylls in mycobacteria. 1. Technical procedures: thin layer chromatographic patterns of mycobacterial pigments. Tubercle $\mathbf{5 1}$, 305-312.

Thомas, D. T. (1967). Swimming pool granuloma. British Medical Journal i, 437.

Tомасн, J. A. \& Franks, S. B. (1953). Granuloma of the skin with tubercle formation following swimming pool injury. Journal of the American Medical Association 151, 724-726.

Torres, J. R., Sands, M. \& Sanders, C. V. (1978). In vitro sensitivity of Mycobacterium marinum to minocycline and doxycycline. Tubercle 59, 193-195.

Tsukamura, M. (1967). Identification of mycobacteria. Tubercle 48, 311-338.

Tsukamura, M. (1976). Numerical classification of slow growing mycobacteria. International Journal of Systematic Bacteriology 26, 409-420.

Tsukamura, M., Mizuno, S., Murata, H., Okada, K. \& Oshima, M. (1973). Differentiation between Mycobacterium kansasii and Mycobacterium marinum. American Review of Respiratory Disease 107, 145-148.

Vestal, A. L. \& Kubica, G. P. (1967). Differential identification of mycobacteria. III. Use of thiacetazone, thiophen-2-carboxylic acid hydrazide and triphenyltetrazolium chloride. Scandinavian Journal of Respiratory Disease 48, 142-148.

Vogel, H. (1958). Mycobacteria from cold-blooded animals. American Review of Respiratory Disease 77, 823-838.

WadDington, E. (1967). An outbreak of swimming pool granuloma. Transactions of the St John's Hospital Dermatological Society 53, 122-124.

Wallace, R. J. \& Wiss, K. (1981). Susceptibility of Mycobacterium marinum to tetracyclines and aminoglycosides. Antimicrobial Agents and Chemotherapy 20, 610-612.

Wayne, L. G., Andrade, L., Froman, S., Käppler, W., Kubala, E., Meissner, G. \& Tsura mura, M. (1978). A cooperative numerical study of Mycobacterium gastri, Mycobacterium kansasii and Mycobacterium marinum. Journal of General Microbiology 109, 319-327.

Wayne, L. G., Doubek, J. R. \& Russell, R. L. (1964). Classification and identification of mycobacteria. I. Tests employing Tween 80 as a substrate. American Review of Respiratory Disease 90, 588-597. 
Wayne, R. P., Tawil, A. B., Coletta, A. J., Hurst, L. C. \& Yecies, L. D. (1981). Mycobacterial tenosynovitis in Long Island fishermen. New York State Journal of Medicine 81, 1091-1094.

Winter, F. E. \& Runyon, E. H. (1965). Prepatella bursitis caused by Mycobacterium marinum (balnei). Journal of Bone and Joint Surgery (American Volume) 47, 375-379.

Wolinsky, E., Gomez, F. \& Zimpfer, F. (1972). Sporotrichoid Mycobacterium marinum infection treated with rifampin-ethambutol. American Review of Respiratory Disease 105, 964-967.

Yamamoto, S., Fujiwara, Y., Saito, H., Taseka, H. \& Oda, S. (1970). A case of multiple skin disease caused by Mycobacterium marinum. Japanese Journal of Dermatology B 80, 142-149.

Zeligman, I. (1972). Mycobacterium marinum granuloma. A disease acquired in the tributaries of Chesapeake bay. Archives of Dermatology 106, 26-31.

Zettergren, L., Zetterberg, B., Malmaren, B. \& Karth, B. (1952). Nya rön beträffande simhallssjukdomen (mycobacteriosis balnei). Svensk Lakartidn 49, 2936-2948. 